\title{
Effectors as Tools in Disease Resistance Breeding Against Biotrophic, Hemibiotrophic, and Necrotrophic Plant Pathogens
}

\author{
Vivianne G. A. A. Vleeshouwers ${ }^{1}$ and Richard P. Oliver ${ }^{2}$ \\ ${ }^{1}$ Wageningen UR Plant Breeding, Wageningen University and Research Centre, P.O. Box 386, 6700 AJ, Wageningen, The \\ Netherlands; ${ }^{2}$ Australian Centre for Necrotrophic Fungal Pathogens, Curtin University, Perth WA 6845, Australia
}

Submitted 16 October 2013. Accepted 17 December 2013.

\begin{abstract}
One of most important challenges in plant breeding is improving resistance to the plethora of pathogens that threaten our crops. The ever-growing world population, changing pathogen populations, and fungicide resistance issues have increased the urgency of this task. In addition to a vital inflow of novel resistance sources into breeding programs, the functional characterization and deployment of resistance also needs improvement. Therefore, plant breeders need to adopt new strategies and techniques. In modern resistance breeding, effectors are emerging as tools to accelerate and improve the identification, functional characterization, and deployment of resistance genes. Since genome-wide catalogues of effectors have become available for various pathogens, including biotrophs as well as necrotrophs, effector-assisted breeding has been shown to be successful for various crops. "Effectoromics" has contributed to classical resistance breeding as well as for genetically modified approaches. Here, we present an overview of how effector-assisted breeding and deployment is being exploited for various pathosystems.
\end{abstract}

In the years since the conceptualization of the role of effectors as an expression of the "extended phenotype", a significant body of knowledge has been generated about these pathogen molecules and their extended in host plants (Dawkins 1978; Hogenhout et al. 2009; Oliver and Solomon 2010). It is not just basic research that has benefitted from increased insight in the molecular plant-microbe interaction. Translational research has embraced effectors for application purposes. In this mini-review, we illustrate how effectors provide a tool in disease resistance breeding, with examples from biotrophic and hemibiotrophic oomycetes and from necrotrophic fungi.

We use a general definition of effectors as pathogen-produced molecules that have a specific effect on one or more genotypes of a host or nonhost plant. This definition stresses function, because it requires that the effector has been shown to induce or suppress a response. It does not differentiate between intraand extracellular effectors or between effectors that have a positive or negative effect on the outcome of the interaction.

Corresponding author: V. G. A. A. Vleeshouwers;

E-mail: vivianne.vleeshouwers@wur.nl; Telephone: +31 317487460 or +31317 482836; Fax: +31317483457.

(C) 2014 The American Phytopathological Society
Thus, our use of the term effector extends to encompass pathogen-associated molecular patterns (PAMPs), microbe-associated molecular patterns, and other elicitors; effectors of biotrophic pathogens (including avirulence $[A v r]$ gene products); and effectors of necrotrophic pathogens (including host-specific toxins).

Biotrophic versus necrotrophic plant pathogens.

Biotrophy is defined as growth and nutrition of the pathogen on living plant tissue. Biotrophic pathogens colonize the host plant in a mode that can be described as stealthy, and evade or suppress defense responses. Hemibiotrophic pathogens first establish a biotrophic interaction with the host plant but, at later infection stages, switch to necrotrophy. Within the filamentous plant pathogens, biotrophy and hemibiotrophy occurs in various clades of fungi as well as oomycetes and are often but not always associated with haustoria formation. Well-studied haustorial fungi include the Basidiomycete rusts that have specialized on a diversity of host species. A beautiful example of the complex perturbations that rust pathogens induce in their host plants is illustrated by the pathogen-induced floral mimicry by Puccinia monoica in Boechera stricta (Cano et al. 2013). Many other rust pathogens have major impacts on agriculture, such as the flax rust fungus Melampsora lini (Duplessis et al. 2011; Ellis et al. 2007) or the wheat stem rust fungus $P$. graminis tritici (Singh et al. 2011). The Ascomycete powdery mildews are biotrophic fungal parasites on a wide range of important crops, such as Blumeria graminis f. sp. hordei on barley (Ridout et al. 2006).

The biotrophic tomato pathogen Cladosporium fulvum (syn. Passalora fulva) does not form haustoria but remains in the apoplast (de Wit et al. 2012). Also, the hemibiotrophic rice blast fungus Magnaporthe oryzae and the maize smut fungus Ustilago maydis do not establish prominent feeding structures; however, they do establish extended interaction zones at sites where intracellular hyphae invaginate the host plasma membrane (Chen et al. 2012a; Djamei and Kahmann 2012).

Plant-pathogenic oomycetes include species with diverse life styles. Downy mildews (Peronosporales) are biotrophic pathogens. Albugo spp. are obligate biotrophs and, for example, cause white rust on Arabidopsis (Links et al. 2011). The biotrophic downy mildew pathogen Hyaloperonospora arabidopsidis also infects Arabidopsis and this plant-oomycete interaction is well characterized (Anderson et al. 2012; Baxter et al. 2010; Coates and Beynon 2010; Fabro et al. 2011). Economically important downy mildews such as Plasmopara viti- 
cola on grape (Yu et al. 2012) or Bremia lactuca on lettuce (Farrara et al. 1987) also have a biotrophic life style. Phytophthora spp. include mostly hemibiotrophic pathogens and cause devastating diseases on a variety of staple crops, fruit, ornamentals, and trees (Erwin and Ribiero 1996). Pythium spp. inhabit water and soil habitats and display saprotrophic growth. On a broad range of plants, Pythium spp. can cause root rot and damping off on seedlings.

Necrotrophy is defined as growth and nutrition of the pathogen on dead or dying plant material. In this mode of infection, death of host plant cells precedes or accompanies colonization of the pathogen. A concentration of necrotrophic pathogens with narrow host-ranges appears in the order Pleosporales (genera Parastagonospora [syn. Stagonospora, Phaeosphaeria], Pyrenophora, Alternaria, Ascochyta, and Cochliobolus) but this taxon also contains Leptosphaeria maculans, a pathogen with an extended biotrophic or quiescent phase, reminiscent of the Mycosphaerella group found in the related order Capnodiales, which also includes $C$. fulvum. The wide-host-range necrotrophs Botrytis and Sclerotinia form another taxonomic group in the Leotiomycetes (interestingly, along with the archetypal biotrophic powdery mildews), whereas the taxonomic placement of the narrow-host-range barley scald pathogen Rhynchosporium secalis remains obscure.

\section{Effectors of biotrophic pathogens.}

Effectors of biotrophic and hemibiotrophic pathogens typically include Avr proteins that are recognized by matching resistance $(\mathrm{R})$ proteins. In the absence of the $\mathrm{R}$ protein, the effectors promote virulence by suppressing innate immune responses, such as PAMP-triggered immunity, in a process termed effectortriggered susceptibility (ETS), which allows the establishment of a biotrophic interaction (Jones and Dangl 2006). ETS is particularly essential during the early infection phases and, in line with this, expression of $A v r$ genes typically peaks at these early time points. Also, hemibiotrophic pathogens initially produce effectors to suppress cell death but, at later phases, these are downregulated and other necrotrophic effectors are induced and come to dominate the interaction. During early biotrophic infection stages of Phytophthora infestans, AVR3a is secreted from haustoria and translocated into the host cell (Whisson et al. 2007). AVR3a stabilizes the plant E3 ligase CMPG1 to mediate suppression of the INF1 elicitin-induced death of host cells at early biotrophic infection phases (Bos et al. 2010).
Recognition of AVR3a by the R3a protein results in the relocalization of each from the cytoplasm to vesicles in the endocytic pathway. This relocalization is required for consequent hypersensitive response (HR) signaling (Engelhardt et al. 2012). After the early biotrophic stage, AVR $3 a$ is downregulated but other effectors, including INF1 and Nep1-like proteins (Qutob et al. 2002), are induced, perhaps helping to promote a switch to necrotrophic infection (Kamoun et al. 1997; Kanneganti et al. 2006).

Avr proteins of biotrophic oomycetes contain an RXLR motif, and the effectors traffic inside the host cells, where they can manipulate plant immunity (Dou et al. 2008b). RXLR effectors are expected to be direct targets of evolutionary forces that drive the antagonistic interplay between oomycete pathogen and host plant (Jiang et al. 2008; Win et al. 2007). The genes encoding RXLR effectors of $P$. infestans were found to reside in gene-sparse and dynamic repeat-rich genome compartments that exhibit accelerated gene evolution rates (Raffaele et al. 2010). This is an example of genomic tillage, a conglomerate of hypermutagenizing processes that seems to be a common feature of effector genes (Oliver 2012). This and various other studies underpin the theory that host specificities of biotrophic pathogens are determined by the effector repertoire that has been shaped during a tight co-evolution with the host (Win et al. 2007). It also explains why resistance genes against the fast-evolving late blight pathogen are defeated so quickly (Fry 2008; Wastie 1991).

\section{Effectors of necrotrophic pathogens.}

Effectors of necrotrophic pathogens include some molecules that were originally designated as host-specific or host-selective toxins (HST). These necrotrophic effectors (NE) encompass an extraordinary range of molecular forms. The Cochliobolus and Alternaria genera produce both polyketide (PKS) and nonribosomal peptide (NRPS), small molecular weight molecules NE (Baker et al. 2006; Walton 2006; Miyamoto et al. 2008, 2009). In contrast, characterized effectors from Parastagonospora nodorum, Pyrenophora tritici-repentis, Rhyncosporium. secalis, Botrytis cinerea, and L. maculans are proteins (Friesen et al. 2009; Liu et al. 2012; Oliver et al. 2012; Rohe et al. 1995; Staats et al. 2007) (Table 1).

The mode of action of necrotrophic effectors involves interaction (not necessarily direct binding) with a dominant host susceptibility gene. Indeed, the first disease resistance gene

Table 1. Overview of effectors of necrotrophic fungi ${ }^{a}$

\begin{tabular}{|c|c|c|c|c|c|c|}
\hline Pathogen & Effector & Structure & $R$ gene & Target & $\begin{array}{l}\text { Positive } \\
\text { selection? }\end{array}$ & Reference \\
\hline Cochliobolus heterostrophus & T-toxin & Polyketide & $?$ & T-Urf13 & NA & Wolpert et al. 2002 \\
\hline C. carbonum & Tox1 & NRPS & $H m-1$ & Histones & NA & Walton 2006 \\
\hline C. victoriae & Victorin & NRPS & $\mathrm{Vb} / \mathrm{Lov} 1$ & Glycine decarboxylase & NA & $\begin{array}{l}\text { Wolpert et al. 2002; } \\
\text { Navarre } 1995\end{array}$ \\
\hline \multicolumn{7}{|l|}{ Alternaria alternata } \\
\hline Tomato & AL & Aminopentol ester & $?$ & Asc & NA & $\begin{array}{l}\text { Wolpert et al. } 2002 ; \\
\text { Tsuge et al. } 2013\end{array}$ \\
\hline Apple & $\mathrm{AM}$ & & & & & Saito et al. 2001 \\
\hline Japanese pear & $\mathrm{AK}$ & & & & & Tanaka and Tsuge 2000 \\
\hline Strawberry & $\mathrm{AF}$ & & & & & \\
\hline Tobacco & AT & & & & & \\
\hline Citrus & $\mathrm{AC}$ & & & & & \\
\hline Rhynchosporium secalis & NIP1 & Protein & Rrs1 & PM ATPase & Yes & Schurch et al. 2004 \\
\hline $\begin{array}{l}\text { Parastagonospora nodorum/ } \\
\text { Pyrenophora tritici-repentis }\end{array}$ & ToxA & Protein & $T s n 1$ & ToxABP & Yes & $\begin{array}{l}\text { McDonald et al. 2013; } \\
\text { Oliver et al. } 2012\end{array}$ \\
\hline P. tritici-repentis & ToxB & Protein & $T s c 2$ & & No & Ciuffetti et al. 2010 \\
\hline Parastagonospora nodorum & Tox3 & Protein & Snn3 & $?$ & Not observed & Liu et al. 2009 \\
\hline P. nodorum & Tox 1 & Protein & Snn1 & $?$ & Yes & Liu et al. 2012 \\
\hline Botrytis cinerea & NEP1-like & Protein & $?$ & $?$ & Yes & Staats et al. 2007 \\
\hline
\end{tabular}

${ }^{a} \mathrm{R}=$ resistance, $\mathrm{NA}=$ not available. 
that was cloned-Hmr-interacted with a necrotrophic effector (Walton 2006). Victorin is an NRPS produced by Cochliobolus victoriae, which causes disease-like symptoms in the natural host oat by interacting with the glycine decarboxylase complex but also in some Arabidopsis thaliana ecotypes that express a gene called Lov1 (Lorang et al. 2007; Sweat et al. 2008). Lov1 has a nucleotide-binding site leucine-rich repeat structure typical of receptor-like disease resistance genes; this is the ultimate confirmation of the parallel between the evolutionary history of $A v r$ genes and HST.

The downstream effects of the interaction between effectors and receptors are diverse. T-toxin and victorin target the mitochondria and ToxA targets the chloroplast. Other targets are unclear thus far but the net effect is induced death of the host cell (Egusa et al. 2008, 2009; Hammond-Kosack and Rudd 2008; Harimoto et al. 2008; Keon et al. 2007; Manning et al. 2009; Rudd et al. 2010; Yakimova et al. 2009). It is conventionally assumed that the role of NE is to induce host cell death so that the pathogen has access to extra nutrients which are used for growth; however, it is also possible that host cell death serves to limit the production of antifungal radicals or molecules or act as a signal for sporulation in the pathogen.

\section{Discovery of effectors from biotrophic pathogens.}

Knowledge on oomycetes, which had been chronically understudied at the molecular level until recent years (Kamoun 2003), was significantly augmented by the genomic era. Large-scale descriptive data emerged from sequencing expressed sequence tags (Kamoun et al. 1999; Qutob et al. 2000; Randall et al. 2005), quickly followed by additional omics data sets such as microarrays and RNA-seq (Haas et al. 2009; Judelson et al. 2008; Kunjeti et al. 2011; Levesque et al. 2010; Savory et al.
2012; Stassen et al. 2012; Ye et al. 2011) and genome sequences of Phytophthora sojae, $P$. ramorum (Tyler et al. 2006), P. infestans (Haas et al. 2009), P. lateralis (Quinn et al. 2013), Pythium ultimum (Levesque et al. 2010), Albugo candida (Links et al. 2011), and H. arabidopsidis (Baxter et al. 2010). The oomycete research community started predicting putative effectors from sequence data sets and, by using algorithms to detect signal peptides, libraries of secreted proteins were identified (Torto et al. 2003). The subsequent detection of the RXLR motif in oomycetes boosted the detection of potential Avr genes in oomycete pathogens (Dou et al. 2008b; Whisson et al. 2007), and catalogs of $A v r$ genes of various oomycete pathogens are being disclosed with unprecedented efficiency (Bailey et al. 2011; Baxter et al. 2010; Fabro et al. 2011; Links et al. 2011; Goritschnig et al. 2012; Stassen et al. 2012, 2013; Vleeshouwers et al. 2011b) (Table 2). Oomycete effectors display an extensive sequence divergence and most of the identified Avr genes have no or very low similarity to other proteins.

Although no universal host-translocation motif has been identified in fungi to date, many effectors are being identified, (e.g., from rust fungi) (Dodds et al. 2009; Ellis et al. 2009; Saunders et al. 2012b). Hundreds of effector candidates have been identified as generally small secreted proteins that are expressed in haustoria, which have no database relatives except for some subfamilies (J. Ellis, personal communication). The first milestone (the generation of comprehensive effector sets) has been achieved for various plant pathogens, including economically important crop pathogens such as some Phytophthora spp. Follow-up studies on individual $\mathrm{R}-\mathrm{Avr}$ pairs are underway to disclose the mechanisms that the pathogen employs to evade $\mathrm{R}$ protein recognition. These insights help to select

Table 2. Identified avirulence (Avr) genes of Phytophthora spp. on economically important food crops

\begin{tabular}{|c|c|c|c|c|c|c|c|c|c|}
\hline \multirow[b]{2}{*}{ Species, $A v r$ gene } & \multicolumn{6}{|c|}{ Allelic variants in virulent strains ${ }^{a}$} & \multirow[b]{2}{*}{ Host } & \multirow[b]{2}{*}{$R$ gene $^{b}$} & \multirow[b]{2}{*}{ References } \\
\hline & Abs & $\mathbf{A A}$ & Shift & Silc & Suppr & Unk & & & \\
\hline \multicolumn{10}{|c|}{ Phytophthora infestans } \\
\hline Avrl & $\cdots$ & $\cdots$ & $\cdots$ & $\cdots$ & $\cdots$ & $X$ & Potato & $R 1$ & $\begin{array}{l}\text { Ballvora et al. 2002; Tyler 2009; } \\
\text { Govers lab unpublished }\end{array}$ \\
\hline Avr2 & $\cdots$ & $X$ & $\cdots$ & $\cdots$ & $\cdots$ & $\cdots$ & $\cdots$ & $R 2$ & $\begin{array}{l}\text { Gilroy et al. 2011; Lokossou et al. 2009; } \\
\text { Saunders et al. 2012a }\end{array}$ \\
\hline$A v r 3 a$ & $\ldots$ & $\mathrm{X}$ & $\cdots$ & $\cdots$ & $\cdots$ & $\cdots$ & $\cdots$ & $R 3 a$ & $\begin{array}{l}\text { Armstrong et al. 2005; Bos et al. 2010; } \\
\text { Engelhardt et al. 2012; Huang et al. } 2005\end{array}$ \\
\hline$A v r 3 b$ & $X$ & $\mathrm{X}$ & $\cdots$ & $X$ & $\ldots$ & $\mathrm{X}$ & $\cdots$ & $R 3 b$ & $\begin{array}{l}\text { Jiang et al. 2006; Li et al. 2011; Rietman 2011; van } \\
\text { der Lee et al. 2001; Vleeshouwers lab, } \\
\text { unpublished }\end{array}$ \\
\hline Avr4 & $\ldots$ & $X$ & $\mathrm{X}$ & $\ldots$ & $\ldots$ & $\ldots$ & $\ldots$ & $R 4^{*}$ & van Poppel et al. 2008 \\
\hline Avrblb1 & $\ldots$ & $\mathrm{X}$ & .. & $\cdots$ & $\mathrm{X}$ & $\cdots$ & $\cdots$ & Rpi-blbl & $\begin{array}{l}\text { Champouret et al. 2009; Chen et al. 2012b; } \\
\text { Song et al. 2003; van der Vossen et al. 2003; } \\
\text { Vleeshouwers et al. } 2008\end{array}$ \\
\hline Avrblb2 & $\ldots$ & $\mathrm{X}$ & .. & $\cdots$ & $\cdots$ & $\mathrm{X}$ & .. & $R p i-b l b 2$ & $\begin{array}{l}\text { Bozkurt et al. 2011; Oh et al. 2009; } \\
\text { van der Vossen et al. } 2005\end{array}$ \\
\hline Avrvnt1 & $\ldots$ & $\ldots$ & $\ldots$ & $\mathrm{X}$ & $\ldots$ & $\ldots$ & $\ldots$ & Rpi-vnt1 & Foster et al. 2009; Pel 2010; Pel et al. 2009 \\
\hline AvrSmiral & $\ldots$ & $\mathrm{X}$ & $\ldots$ & $\ldots$ & $\ldots$ & $\mathrm{X}$ & $\ldots$ & Rpi-Smiral* & Rietman et al. 2012 \\
\hline AvrSmira2/Avr8 & $\ldots$ & ... & $\ldots$ & .. & $\cdots$ & $\mathrm{X}$ & $\cdots$ & Rpi-Smira2/R8* & $\begin{array}{l}\text { Kwang-Ryong 2013; Kwang-Ryong et al. 2011; } \\
\text { Rietman et al. } 2012\end{array}$ \\
\hline \multicolumn{10}{|r|}{ 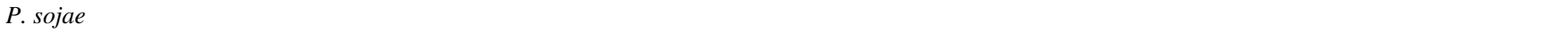 } \\
\hline Avrla & $\mathrm{X}$ & $\ldots$ & $\ldots$ & $\mathrm{X}$ & $\ldots$ & ... & Soybean & Rps $1 a^{*}$ & Qutob et al. 2009 \\
\hline$A v r 1 b$ & $\ldots$ & $\mathrm{X}$ & $\ldots$ & $\mathrm{X}$ & $\ldots$ & $\ldots$ & $\ldots$ & $R p s 1 b^{*}$ & Cui et al. 2012; Dou et al. 2008a; Shan et al. 2004 \\
\hline Avrlc & $\mathrm{X}$ & $\ldots$ & $\ldots$ & $\mathrm{X}$ & $\ldots$ & $\ldots$ & $\ldots$ & Rps $1 c^{*}$ & Gijzen lab unpublished \\
\hline Avrld & $\mathrm{X}$ & $\ldots$ & $\ldots$ & $\ldots$ & $\ldots$ & $\ldots$ & $\ldots$ & $\operatorname{Rps} 1 d^{*}$ & Na et al. 2013; Yin et al. 2013 \\
\hline Avrlk & $\ldots$ & $\ldots$ & $\mathrm{X}$ & $\ldots$ & $\ldots$ & $\ldots$ & $\ldots$ & Rps $1 k^{*}$ & Gao and Bhattacharyya 2008; Song et al. 2013 \\
\hline Avr3a/5 & $\ldots$ & $\mathrm{X}$ & $\ldots$ & $\mathrm{X}$ & $\ldots$ & $\ldots$ & $\ldots$ & $\operatorname{Rps} 3 a / 5 *$ & Dong et al. 2009, 2011b; Qutob et al. 2009 \\
\hline$A v r 3 b$ & $\ldots$ & $\mathrm{X}$ & $\mathrm{X}$ & $\ldots$ & $\ldots$ & $\ldots$ & $\ldots$ & $R p s 3 b^{*}$ & Dong et al. 2011a \\
\hline$A v r 3 c$ & $\ldots$ & $\mathrm{X}$ & $\ldots$ & $\ldots$ & $\ldots$ & $\cdots$ & $\ldots$ & $\operatorname{Rps} 3 c^{*}$ & Dong et al. 2009 \\
\hline Avr4/6 & $\ldots$ & $\ldots$ & $\ldots$ & $\mathrm{X}$ & $\ldots$ & $\ldots$ & $\ldots$ & $\operatorname{Rps} 4 / 6^{*}$ & Dou et al. 2010; Sandhu et al. 2004 \\
\hline
\end{tabular}

${ }^{a}$ Diverse characteristics that correlate with a gain-of-virulence, such as gene absence (Abs) (e.g., through deletion or absence of the locus), amino acid (AA) mutation, frame shift (Shift), silencing (Silc), or suppression by another effector (Suppr), if known, are listed for each effector; Unk = under study or unknown.

${ }^{\mathrm{b}}$ Resistance $(R)$ genes; * indicates $R$ gene not cloned. 
those $R$ genes that can resist the widest spectrum of the pathogen population, and that are potentially more durable (Table 2 ).

\section{Discovery of effectors from necrotrophic pathogens.}

Various effectors have been described from necrotrophic fungi (Table 1). All the effectors mentioned in the table were isolated and purified from culture filtrates. There was a clear contrast here with Cladosporium fulvum whose effectors were obscured or not produced at all in vitro (de Wit et al. 2009), and obligate biotrophs whose effectors are produced mainly from haustoria. PKS and NRPS effectors were structurally characterized, and the genes encoding them were subsequently discovered. Many such genes have been found on dispensable chromosomes (Hatta et al. 2002; Johnson et al. 2001). Dispensable (also known as accessory, supernumerary, or "B") chromosomes are defined as large genetic elements that are not found in all strains of a species. They are typically highly variable and rapidly mutating (Croll and McDonald 2012).

The genome sequence of Parastagonospora nodorum had a direct and immediate impact on effector studies. The presence of a gene very similar to PtrToxA in P. nodorum was readily apparent, stimulating its functional characterization (Friesen et al. 2006). The discovery of Toxl and Tox3 was directly facilitated by the genome sequence. The genome was scanned for proteins that were small, secreted, cysteine rich, variable in other strains, and had no homologues in other species. Thus far, no more specific feature such as the RXLR motif in oomycetes has emerged as a common feature of necrotrophic effectors. It should also be noted that the ab initio annotation of the $P$. nodorum genome failed to correctly predict the exon boundaries of ToxA, Tox1, and Tox3. It appears that necrotrophic effector genes have, thus far, been poorly predicted by existing gene-finding programs.

\section{Exploiting effectors in breeding and $\boldsymbol{R}$ gene deployment against biotrophic pathogens.}

"Effectoromics", defined as a high-throughput, functional genomics approach that uses effectors for probing plant germplasm to detect $R$ genes, has proven to be a potent contributor to modern breeding. The strategy was pioneered for Phytophthora infestans and potato and, in the past few years, a catalog of $R$ and Avr genes has become available (Hein et al. 2009; Vleeshouwers et al. 2011a and b). Knowledge of the molecular interaction between $R$ and $A v r$ genes is being directly exploited by potato breeders. In addition to applying molecular markers for marker-assisted selection, effectors are now recognized as functional markers that accelerate and improve disease resistance breeding (Table 3 ).

Below, we summarize how effectors are being applied in breeding for resistance to $P$. infestans in potato. We mention four aspects by which the knowledge of diversity and function of effectors is being utilized to improve resistance to late blight.

First, exploiting effectors provides a tool to accelerate $R$ gene cloning. Obviously, the time-consuming generation of stable transformations can be by-passed by quick functional assays based on transient complementation tests. Fortunately, Agrobacterium-based methods such as agroinfiltration and $\mathrm{Po}$ tato virus $X$ (PVX) agroinfection are effective in Solanum plants (Du et al. 2013; Rietman et al. 2012).

Second, effectors are used to determine functional redundancy. To get ahead in the "arms race" with the fast-evolving $P$. infestans, potato breeders pursue a continuous inflow of new $R$ genes from wild germplasm (Jupe et al. 2012; Vleeshouwers et al. 2011a). However, genetic crossing barriers remain a problem in potato breeding and can delay $R$ gene introgression for decades (Hermsen and Ramanna 1973; Tiemens-Hulscher et al. 2013). Effectoromics has accelerated this process. Functional allele mining by PVX agroinfection with AVRblb1 was performed to identify homologs of the broad-spectrum RB/Rpi-blbl gene, which originates from Solanum bulbocastanum that is not directly sexually compatible. Specific cell death responses to AVRblb1 were quickly detected in S. stoloniferum that is directly crossable with cultivated potato and was found to carry Rpi-stol, a functional homolog of Rpi-blbl (Vleeshouwers et al. 2008). Currently, the Rpi-stol gene is efficiently used for the classic introgression into cultivated potato-breeding material.

In addition, $R$ genes can be classified based on responses to effectors to avoid redundant breeding or cloning efforts. This is particularly important for $R$ genes that confer a broad-spectrum resistance and for which diagnostic pathogen races are not available (Lokossou et al. 2010). Indeed, currently, potato breeders apply functional effector assays (such as agroinfiltration) on their genitors, to guarantee that new sources that enter the breeding pipeline confer additional, novel recognition specificities.

A third aspect is accurately detecting the diverse resistance specificities in plant material. Natural stacks in wild germplasm as well as pyramided $R$ genes in potato cultivars are more efficiently and precisely distinguished by individual effectors than by differential sets of pathogen isolates. This was shown for the "differential" potato lines MaR8, MaR9, and 'Sarpo Mira', in which four, seven, and five individual $R$ genes, respectively, were detected by their matching effectors (Black et al. 1953; Kim et al. 2011; Rietman et al. 2012).

Effectors aid in "Mendelization" of field resistance. Field resistance often confers weak phenotypes that cannot accurately be determined in routine disease assays in the laboratory; therefore, breeding for field resistance has remained a challenge, especially for the highly heterozygous potato. However, functional assays with effectors have enabled specific de-

Table 3. Overview of aspects of effector-assisted breeding and deployment for biotrophic plant pathogens ${ }^{\mathrm{a}}$

\begin{tabular}{|c|c|c|}
\hline $\begin{array}{l}\text { Effector-assisted breeding and } \\
\text { deployment }\end{array}$ & Exploit effectors & Approach \\
\hline$R$ gene cloning & Accelerate & Functional assay with $A v r$ gene (co-infiltrations) \\
\hline \multirow{2}{*}{ Distinguish functional redundancy } & Circumvent crossing barriers & Functional allele-mining with $A v r$ gene in resistant germplasm \\
\hline & Avoid redundant breeding efforts & Functional assay with $A v r$ gene \\
\hline \multirow[t]{4}{*}{ Detect specificity } & Dissect natural stacks of $R$ genes in breeding lines & Functional assay with $A v r$ gene \\
\hline & $\begin{array}{l}\text { Functional tests of individual } R \text { genes in genetically } \\
\text { modified stacks }\end{array}$ & Functional assay with $A v r$ gene \\
\hline & Mendelize field resistance & $\begin{array}{l}\text { Functional assay with } A v r \text { gene } \\
\text { (effectors as functional markers during breeding) }\end{array}$ \\
\hline & Detect expanded recognition specificity of $R$ genes & Accurate detection of responses to allelic diversity of effectors \\
\hline \multirow[t]{2}{*}{$R$ gene deployment } & Targeted choice of $R$ genes & Spacio-temporal monitoring effectors in pathogen population \\
\hline & Decision control measures & In-season monitoring effectors in local pathogen population \\
\hline
\end{tabular}

${ }^{\text {a }} R=$ resistance and $A v r=$ avirulence genes. 
tection of a "field resistance gene", Rpi-Smira2, in Sarpo Mira (Rietman et al. 2012). This is a promising advance for classical breeders, who now can accurately introgress partial resistance genes or quantitative trait loci (QTL) in potato by using effectors as functional markers.

An ultimate advance of effector-based breeding is expanding the effector recognition specificity of a given $R$ gene. R proteins that recognize more, or ideally all, allelic forms of $A v r$ genes are expected to provide a broad spectrum of resistance, provided that the effector is essential to pathogen fitness or virulence. For such studies, basic knowledge of the effector is required. An engineered $R 3 a$ that recognizes both $\mathrm{AVR} 3 \mathrm{a}^{\mathrm{KI}}$ as well as AVR $3 \mathrm{a}^{\mathrm{EM}}$ targets both allelic forms of $A v r 3 a$ that are present in the $P$. infestans population (Kamoun et al. 2012). Expanded recognition specificity can be due to a single amino-acid change in the $\mathrm{R}$ protein, and genome editing technologies are emerging, such as application of transcription activator-like effectors (Boch et al. 2009; Bogdanove and Voytas 2011) or CRISPr (Nekrasov et al. 2013), which may allow single-nucleotide changes to an endogenous gene and, thus, are anticipated to avoid current policy definitions of genetically modified organisms.

Fourth, effectors can assist in $R$ gene deployment in agriculture. Ideally, the choice of which $R$ gene to deploy should be based on properties of the effector. In contrast to dispensable effectors such as Avr4 of P. infestans (van Poppel et al. 2008), effectors that are essential for full virulence imply that corresponding $R$ genes are good targets for durable resistance breeding. The spatio-temporal deployment of $R$ genes can build on information of the allelic diversity of effectors in pathogen populations and help breeders to evaluate the potential of a given $R$ gene. Using sensitive modern techniques, it is possible to rapidly profile the effector repertoires of epidemic $P$. infestans genotypes. This effector profiling in pathogen populations can assist in decision making for $R$-gene deployment and chemical control measures in current and subsequent potatogrowing seasons. A successful experiment was performed in potato field trials. In-season sampling of leaves that showed late blight symptoms was followed by a high-throughput detection of effectors by automated quantitative polymerase chain reaction (G. Kessel, H. Schepers, and T. van der Lee; personal communication). This information was fed into a warning system for the presence of isolates with virulent alleles and a subsequent decision system to apply chemical control only when virulent alleles were detected. With the proofof-principle for effective effector monitoring delivered in this experiment, such strategies can now be further optimized for practical use.

In current breeding programs for late blight resistance in the Netherlands, various companies are making use of effectors for diagnostic purposes. In the $R$ gene identification pipeline, programs are also targeted to identify and study the matching Avr for genetic diversity and expression during infection. Such knowledge is used as a prediction criterion of whether an $R$ gene will be effective in the field and useful for breeding. A consortium of potato companies have agreed to commercialize new $R$ genes; not as single genes, but released in packages of multiple, broad-spectrum $R$ genes, as stacked trans- or preferably as cis-genes (Schouten et al. 2006). Transient expression of effectors in these genetically modified plants (e.g., by agroinfiltration) then provides functional verification of whether all components of the stack are functioning.

\section{Exploitation of necrotrophic effectors}

to improve crop protection against necrotrophic pathogens.

The role of necrotrophic effectors in promoting virulence can also be directly exploited to select quantitatively more resistant germplasm. The precondition for the simple applica- tion of effectors to disease resistance breeding is that crop varieties differ in their response to effectors and that insensitive cultivars are more resistant to the disease. Effector assays avoid, or at least reduce, the need for infection assays and field trials. It is also an example of the direct application of pathogen genomics in crop protection.

The Southern corn leaf blight epidemic destroyed approximately $12 \%$ of the corn crop in the United States in 1970. Up to that point, Cochliobolus heterostrophus had been regarded as a pathogen of minor economic impact (Tatum 1971). The epidemic was caused by a new race of the pathogen called race $\mathrm{T}$ which produced a necrotrophic effector called T-toxin. Exploitation of the finding was rapid and decisive. It was clear from the outset that only corn carrying the cytoplasmic male sterility $\mathrm{T}$ (cms-T) locus was susceptible to the pathogen. It was subsequently shown to be sensitive to T-toxin (Gengenbach et al. 1977; Yoder 1980). The target of T-toxin was later shown to be a mitochondrial protein called t-URF13. Hybrid corn production used a number of CMS loci to facilitate seed production. Therefore, it was a simple matter to apply, taking only two seasons to completely eliminate cms-T lines from the seed production systems. In this way, the status quo was restored and Southern corn leaf blight has remained at a low level ever since.

Other species in the Cochliobolus genus (previously called Helminthosporium) were found to produce small molecular weight effectors. These include $\mathrm{HC}$ toxin produced by $C$. carbonum, the causal agent of Northern corn leaf blight. HC toxin is a cyclic tetrapetide and insensitivity is encoded by the first cloned disease resistance gene, Hml (Johal and Briggs 1992).

C. victoriae, causal agent of oat Victoria blight, produces victorin. Resistance to Victoria blight at the $V b$ locus was associated with insensitivity to victorin but also susceptibility to the crown rust disease. Effector sensitivity was used to screen tissue culture explants of oat (Rines and Luke 1985). Plants that were insensitive were all found to be susceptible to the rust. There is no record that these lines were used to breed released cultivars. Indeed, to our knowledge, none of the Cochliobolus effectors have been needed by breeders in breeding programs. It is likely that insensitive germplasm was abundant and suitable for immediate use (J. D. Walton, personal communication).

Alternaria alternata has been extensively studied and shown to produce a series of specific necrotrophic effectors (Tsuge et al. 2013). The AK effector produced by the Japanese pear black spot pathogen was used to select insensitive mutants derived from a long-term radiation mutation program (Masuda et al. 1997). Although the lines were relatively resistant to the disease, they have not been used directly in breeding. The AM effector produced by the apple pathogen has been used to select mutants produced by in vitro culture of apples (Saito et al. 2001). Again, it appears that such explants have not been used to generate new cultivars.

One of the first proteinaceous necrotrophic effectors to be fully characterized is NIP1, produced by the barley scald pathogen $R$. secalis (Avrova and Knogge 2012). NIP1 induces necrosis in barley lines carrying the Rrs gene and, thus, predicts resistance to some races of the pathogen (Rohe et al. 1995). Once again, there is no evidence that breeders used the effector. The explanation was that RRs 1 resistance was already broken by different races of the pathogen and, therefore, resistance was not regarded as a useful breeding target.

The wheat tan spot disease caused by Pyrenophora triticirepentis has two well-characterized proteinaceous effectors (ToxA and ToxB) and one less-well-characterized non-protein effector (ToxC) (Effertz et al. 2002). Both ToxA and ToxB have been expressed from microbial systems and studied in great detail (Ciuffetti et al. 2010). ToxA is present as a single 
copy in approximately $80 \%$ of the world's isolates, though prevalence is thought to vary around the world. ToxB is generally rare and appears to be absent from isolates in Australia (Antoni et al. 2010).

ToxA is recognized by the product of the gene $T s n 1$, located on chromosome 5BL (Faris et al. 2010). Susceptibility to tan spot has consistently been linked to the Tsn1 locus in several wheat-mapping populations (Faris et al. 2013; Friesen et al. 2002, 2003), including those from Australia (Cheong et al. 2004). A convenient semidominant marker had been made available to breeders. However, neither the marker nor the effector was exploited by breeders before 2009.

Research into necrotrophic effectors in Parastagonospora nodorum began with the discovery of secreted proteins that differentially induced necrotic reactions in wheat cultivars that identified sensitivity loci in wheat that co-located with disease susceptibility. Sensitive cultivars were found to be more susceptible to the disease. Genetic mapping of the effector sensitivity co-localized with QTL for susceptibility. The first such recognized effector to be purified was Tox1 (Liu et al. 2004). The genome sequence had not yet been obtained; therefore, identification of the gene was delayed. The release of the genome sequence in 2005 (Hane et al. 2007) revealed a gene very similar to the already cloned Pyrenophora tritici-repentis ToxA gene (Friesen et al. 2006). This was unexpected because Tox1 had properties incompatible with the structure of ToxA. The availability of functional genomic tools allowed the appropriate experiments to be done that showed that the ToxA-Tsn 1 interaction was also important in the Parastagonospora nodorum pathosystem (Liu et al. 2006). Subsequent experiments fully characterized the ToxA, Tox1, and Tox3 interactions (Liu et al. 2009, 2012; Oliver et al. 2012).

Delivery of ToxA to Australian wheat breeders began in 2009. Semipurified ToxA derived from an Escherichia coli expression system was made and, by 2012, enough ToxA to test 30,000 was being dispatched annually, together with approximately 6,000 doses of Tox 1 and Tox3. Why were Australian breeders willing to invest so many resources in the use of these effectors? Why did they prefer to use the effectors when diagnostic DNA markers were available? How much impact has it had?

The answers to these questions have a variety of origins. Tan spot affects wheat throughout the Australian wheat belt and a report released in 2009 indicated that annual losses of \$212 million were occurring (Murray and Brennan 2009). In addition, losses to $P$. nodorum amounted to $\$ 108$ million, despite the disease being apparently limited to Western Australia. These losses greatly exceeded the losses to all three rust diseases, all other pathogens, and many abiotic stresses. Tan spot and $P$. nodorum were major issues that needed urgent attention.

The existing system of cultivar characterization classified tan spot resistance in the field on a 10-point scale, although there were no cultivars rated as 8,9 , or 10 (resistant). It was a simple matter to test the ToxA sensitivity of samples of each cultivar. This showed that susceptibility was strongly correlated with effector sensitivity; sensitive cultivars have been found to be consistently in the range of 1 to 4 and insensitive cultivars 5 to 7, with just one or two exceptions. These are expected to be due to the presence of other effectors (Faris et al. 2013). Breeders took notice and quickly adopted the test because this promised to reduce or eliminate the need for field trials for tan spot. The elimination of Tsnl from current cultivars promises to bring tan spot down to the level of a moderate, if still economically significant, disease.

The situation for $P$. nodorum was less clear-cut. Testing of all three effectors in current cultivars indicates that sensitivity to just one effector is sufficient to induce significant disease susceptibility. Hence, the task for the breeder is to eliminate sensitive alleles for all three effectors. This is a simpler task than applying markers to weak disease QTLs and promises to incrementally improve disease resistance. In effect, breeders are cooperating in a test to determine whether effector-assisted breeding is the best way to reduce disease susceptibility.

Breeders responded more positively to the effector assays than to the functionally equivalent molecular markers. The effector assays could be carried out on seedlings and adult plants up to approximately 6 weeks old and could be conducted in glasshouses or in field plots. Several thousand individual plants could be tested by a single operator in a single day. The results were visible and clear within a week. Breeders could decide to eliminate sensitive plants immediately, thus saving time and resources later on. In comparison, marker assays require DNA to be prepared and costly assays performed in a remote laboratory weeks or months later. Incorporation of the results can only take place after harvest. Critically, no markers for P. nodorum derived from disease QTL have been validated sufficiently for adoption by the breeders.

The impact of the use of the ToxA, ToxA-1, and ToxA-3 can be estimated by comparing the area of wheat grown to effector-sensitive wheat. The area sown to ToxA-sensitive wheat in Western Australia fell from $30.4 \%$ in $2009-2010$ to $16.9 \%$ in 2012-2013. This equates to a reduction of approximately 700,000 hectare. Susceptible wheat typically has a 0.3 tons per hectare reduction in yield, or 200,000 tons. Average wheat prices are approximately $\$ 250$ per ton; therefore, the saving is $\$ 50$ million. A similar scale reduction can be expected elsewhere in Australia. A large part of this reduction in area can be ascribed to the increased attention growers have paid to the losses caused by tan spot. Therefore, they have chosen to use more resistant cultivars. Much greater reductions in losses can be expected when breeders release varieties bred with the help of the effectors. This reduction should be a large fraction of the approximately $\$ 300$ million ascribed to these diseases in 2008.

\section{Perspectives.}

There are basically three requirements for further expanding the application of effectors in breeding for resistance to the various types of plant pathogens.

First, genomics pipelines are needed to generate a sequence database of pathogens and expand the repertoire of known effectors (Pais et al. 2013). In addition to genome-wide effector repertoires, expression data provide major contributions to specifically reveal those effectors that are upregulated during interaction.

Second, from the wealth of effectors, educated choices can be made. "Achilles heel" effectors (Laugé et al. 1998), core effectors that are conserved between different epidemic strains (Cooke et al. 2012), or effectors that are demonstrated to be important for virulence provide useful knowledge for breeders and provide ideal targets for potentially broad-spectrum and more durable $R$ genes. To gain deeper insights, the modes of action of individual effectors and their interactions with effector targets and matching immune receptors should be studied (van der Hoorn and Kamoun 2008). For example, in some cases, distantly-related immune receptors interact with the same matching effector, and virulence targets can then provide information on whether the immune receptors are prone to the same vulnerabilities (P. Birch, personal communication). Insights into the evolution or co-evolution of immune receptors and effectors can explain the observed redundancy of $R$ genes within certain $R$ families and the redundancy of recognition of effector targets (I. Hein, personal communication). Also, the behavior of certain $\mathrm{R}$ proteins, such as the relocalizations of 
R3a following perception of AVR3a from Phytophthora infestans (Engelhardt et al. 2012), needs further study to determine whether this phenomenon is related to the $\mathrm{R}$ protein family, the effector family, or both. Such depth of mechanistic insights will ultimately help to provide the most promising immune receptors to the community. In addition, apoplastic effectors that interact with pathogen recognition receptors at the first layer of immunity can be sourced across families (Lacombe et al. 2010), and such immune receptors can add a new dimension in breeding. Ultimately, plant breeders can combine immunity layers that are populated with potentially durable immune receptors.

The third challenge is to optimize functional assays for host plants. For solanaceous hosts, transient assays based on Agrobacterium have been quite effective; however, for many crops, functional assays can be limiting. On soybean, the leaves are not amenable to transient Agrobacterium-based assays, and this is also the case on monocot hosts. This issue has been a major limitation for exploiting effectors for various pathogens. Alternative bacterial systems for transient expression and viralbased systems are being developed to overcome this problem. The bacterial type III secretion system (T3SS) can be used to translocate effectors from various pathogens (Rentel et al. 2008; Sohn et al. 2007), and an effector detector vector system that is based on T3SS was used to successfully translocate effectors of M. oryzae into rice cytoplasm (Sharma et al. 2013). Using the T3SS-based effector-to-host analyzer system, an effector candidate caused HR on wheat carrying the $S r 22$ gene (Thomas et al. 2009; Upadhyaya et al. 2014). The system has also been optimized for soybean and related legumes, and candidate $R$ genes against essential effectors from the rot pathogen $P$. sojae have been identified (J. M. McDowell, K. Fedkenheuer, and M. Fedkenheuer personal communication).

Altogether, new advances are emerging and promise to facilitate the incorporation of effectoromics and other pathogeninformed strategies in a broad range of host plants (Dangl et al. 2013).

\section{ACKNOWLEDGMENTS}

Research in the authors' laboratories is funded by the Australian Grains Research, Development Corporation and the Australian Research Council; the Dutch Umbrella Program from the Ministry of Agriculture; and an NWO-VIDI grant 12378. We thank P. Birch, S. Kamoun, I. Hein, M. Gijzen, J. Ellis, J. M. McDowell, N. Champouret, H. Rietman, J. Du, R. Visser, E. Jacobsen, J. Vossen, T. Tsuge, K. Ikeda, O. Yoder, J. Walton, W. Knogge, and T. Wolpert for helpful advice; and many colleagues for their helpful discussions and collaboration.

\section{LITERATURE CITED}

Anderson, R. G., Casady, M. S., Fee, R. A., Vaughan, M. M., Deb, D., Fedkenheuer, K., Huffaker, A., Schmelz, E. A., Tyler, B. M., and McDowell, J. M. 2012. Homologous RXLR effectors from Hyaloperonospora arabidopsidis and Phytophthora sojae suppress immunity in distantly related plants. Plant J. 72:882-893.

Antoni, E. A., Rybak, K., Tucker, M. P., Hane, J. K., Solomon, P. S., Drenth, A., Shankar, M., and Oliver, R. P. 2010. Ubiquity of ToxA and absence of ToxB in Australian populations of Pyrenophora triticirepentis. Australas. Plant Pathol. 39:63-68.

Armstrong, M. R., Whisson, S. C., Pritchard, L., Bos, J. I. B., Venter, E., Avrova, A. O., Rehmany, A. P., Bohme, U., Brooks, K., Cherevach, I., Hamlin, N., White, B., Frasers, A., Lord, A., Quail, M. A., Churcher, C., Hall, N., Berriman, M., Huang, S., Kamoun, S., Beynon, J. L., and Birch, P. R. J. 2005. An ancestral oomycete locus contains late blight avirulence gene Avr3a, encoding a protein that is recognized in the host cytoplasm. Proc. Natl. Acad. Sci. U.S.A. 102:7766-7771.

Avrova, A., and Knogge, W. 2012. Rhynchosporium commune: A persistent threat to barley cultivation. Mol. Plant Pathol. 13:986-997.

Bailey, K., Çevik, V., Holton, N., Byrne-Richardson, J., Sohn, K. H., Coates, M., Woods-Tör, A., Murat Aksoy, H., Hughes, L., Baxter, L.,
Jones, J. D. G., Beynon, J., Holub, E. B., and Tör, M. 2011. Molecular cloning of ATR5Emoy2 from Hyaloperonospora arabidopsidis, an avirulence determinant that triggers RPP5-mediated defense in Arabidopsis. Mol. Plant-Microbe Interact. 24:827-838.

Baker, S. E., Kroken, S., Inderbitzin, P., Asvarak, T., Li, B. Y., Shi, L., Yoder, O. C., and Turgeon, B. G. 2006. Two polyketide synthase-encoding genes are required for biosynthesis of the polyketide virulence factor, T-toxin, by Cochliobolus heterostrophus. Mol. Plant-Microbe Interact. 19:139-149.

Ballvora, A., Ercolano, M. R., Weiss, J., Meksem, K., Bormann, C. A., Oberhagemann, P., Salamini, F., and Gebhardt, C. 2002. The Rl gene for potato resistance to late blight (Phytophthora infestans) belongs to the leucine zipper/NBS/LRR class of plant resistance genes. Plant J. 30:361-371.

Baxter, L., Tripathy, S., Ishaque, N., Boot, N., Cabral, A., Kemen, E., Thines, M., Ah-Fong, A., Anderson, R., Badejoko, W., Bittner-Eddy, P., Boore, J. L., Chibucos, M. C., Coates, M., Dehal, P., Delehaunty, K., Dong, S., Downton, P., Dumas, B., Fabro, G., Fronick, C., Fuerstenberg, S. I., Fulton, L., Gaulin, E., Govers, F., Hughes, L., Humphray, S., Jiang, R. H. Y., Judelson, H., Kamoun, S., Kyung, K., Meijer, H., Minx, P., Morris, P., Nelson, J., Phuntumart, V., Qutob, D., Rehmany, A., Rougon-Cardoso, A., Ryden, P., Torto-Alalibo, T., Studholme, D., Wang, Y., Win, J., Wood, J., Clifton, S. W., Rogers, J., Van den Ackerveken, G., Jones, J. D. G., McDowell, J. M., Beynon, J., and Tyler, B. M. 2010. Signatures of Adaptation to Obligate Biotrophy in the Hyaloperonospora arabidopsidis Genome. Science 330:1549-1551.

Black, W., Mastenbroek, C., Mills, W. R., and Peterson, L. C. 1953. A proposal for an international nomenclature of races of Phytophthora infestans and of genes controlling immunity in Solanum demissum derivatives. Euphytica 2:173-178.

Boch, J., Scholze, H., Schornack, S., Landgraf, A., Hahn, S., Kay, S., Lahaye, T., Nickstadt, A., and Bonas, U. 2009. Breaking the code of DNA binding specificity of TAL-type III effectors. Science 326:15091512.

Bogdanove, A. J., and Voytas, D. F. 2011. TAL effectors: Customizable proteins for DNA targeting. Science 333:1843-1846.

Bos, J. I. B., Armstrong, M. R., Gilroy, E. M., Boevink, P. C., Hein, I., Taylor, R. M., Zhendong, T., Engelhardt, S., Vetukuri, R. R., Harrower, B., Dixelius, C., Bryan, G., Sadanandom, A., Whisson, S. C., Kamoun, S., and Birch, P. R. J. 2010. Phytophthora infestans effector AVR3a is essential for virulence and manipulates plant immunity by stabilizing host E3 ligase CMPG1. Proc. Natl. Acad. Sci. U.S.A. 107:9909-9914.

Bozkurt, T. O., Schornack, S., Win, J., Shindo, T., Ilyas, M., Oliva, R., Cano, L. M., Jones, A. M. E., Huitema, E., van der Hoorn, R. A. L., and Kamoun, S. 2011. Phytophthora infestans effector AVRblb2 prevents secretion of a plant immune protease at the haustorial interface. Proc. Natl. Acad. Sci. U.S.A. 108:20832-20837.

Cano, L. M., Raffaele, S., Haugen, R. H., Saunders, D. G. O., Leonelli, L., MacLean, D., Hogenhout, S. A., and Kamoun, S. 2013. Major Transcriptome Reprogramming Underlies Floral Mimicry Induced by the Rust Fungus Puccinia monoica in Boechera stricta. PLoS One 8:e75293. Published online.

Champouret, N., Bouwmeester, K., Rietman, H., van der Lee, T., Maliepaard, C., Heupink, A., van de Vondervoort, P. J., Jacobsen, E., Visser, R. G., van der Vossen, E. A., Govers, F., and Vleeshouwers, V. G. A. A. 2009. Phytophthora infestans isolates lacking class I ipiO variants are virulent on Rpi-blb1 potato. Mol. Plant-Microbe Interact. 22:1535-1545.

Chen, S., Songkumarn, P., Venu, R. C., Gowda, M., Bellizzi, M., Hu, J., Liu, W., Ebbole, D., Meyers, B., Mitchell, T., and Wang, G.-L. 2012a. Identification and characterization of in planta-expressed secreted effector proteins from Magnaporthe oryzae that induce cell death in rice. Mol. Plant-Microbe Interact. 26:191-202.

Chen, Y., Liu, Z., and Halterman, D. A. 2012b. Molecular determinants of resistance activation and suppression by Phytophthora infestans effector IPI-O. PLoS Pathog. 8:e1002595. Published online.

Cheong, J., Wallwork, H., and Williams, K. J. 2004. Identification of a major QTL for yellow leaf spot resistance in the wheat varieties Brookton and Cranbrook. Aust. J. Agric. Res. 55:315-319.

Ciuffetti, L. M., Manning, V. A., Pandelova, I., Betts, M. F., and Martinez, J. P. 2010. Host-selective toxins, Ptr ToxA and Ptr ToxB, as necrotrophic effectors in the Pyrenophora tritici-repentis-wheat interaction. New Phytol. 187:911-919.

Coates, M. E., and Beynon, J. L. 2010. Hyaloperonospora arabidopsidis as a pathogen model. Annu. Rev. Phytopathol. 48:329-345.

Cooke, D. E., Cano, L. M., Raffaele, S., Cooke, L. R., Etherington, G., Deahl, K. L., Farrer, R. A., Gilroy, E. M., Goss, E. M., Grünwald, N. J., Hein, I., MacLean, D., McNicol, J., Randall, E., Oliva, R., Pel, M. A., Shaw, D. S., Squires, J., Taylor, M. C., Vleeshouwers, V. G., Birch, P. R., Lees, A. K., and Kamoun, S. 2012. Genome analyses of an aggres- 
sive and invasive lineage of the Irish potato famine pathogen. PLoS Pathog. 8:e1002940. Published online.

Croll, D., and McDonald, B. A. 2012. The accessory genome as a cradle for adaptive evolution in pathogens. PLoS Pathog. 8:e1002608. Published online.

Cui, L., Yin, W., Dong, S., and Wang, Y. 2012. Analysis of polymorphism and transcription of the effector gene Avrlb in Phytophthora sojae isolates from China virulent to Rps 1b. Mol. Plant Pathol. 13:114-122.

Dangl, J. L., Horvath, D. M., and Staskawicz, B. J. 2013. Pivoting the plant immune system from dissection to deployment. Science 341:746751.

Dawkins, R. 1978. Replicator selection and the extended phenotype. Z Tierpsychol. 47:61-76.

de Wit, P. J. G. M., Mehrabi, R., Van Den Burg, H. A., and Stergiopoulos, I. 2009. Fungal effector proteins: Past, present and future: Review. Mol Plant Pathol. 10:735-747.

de Wit, P. J. G. M., van der Burgt, A., Ökmen, B., Stergiopoulos, I., AbdElsalam, K. A., Aerts, A. L., Bahkali, A. H., Beenen, H. G., Chettri, P. Cox, M. P., Datema, E., de Vries, R. P., Dhillon, B., Ganley, A. R., Griffiths, S. A., Guo, Y., Hamelin, R. C., Henrissat, B., Kabir, M. S., Jashni, M. K., Kema, G., Klaubauf, S., Lapidus, A., Levasseur, A., Lindquist, E., Mehrabi, R., Ohm, R. A., Owen, T. J., Salamov, A., Schwelm, A., Schijlen, E., Sun, H., van den Burg, H. A., van Ham, R. C. H. J., Zhang, S., Goodwin, S. B., Grigoriev, I. V., Collemare, J., and Bradshaw, R. E. 2012. The genomes of the fungal plant pathogens Cladosporium fulvum and Dothistroma septosporum reveal adaptation to different hosts and lifestyles but also signatures of common ancestry. PLoS Genet. 8:e1003088. Published online.

Djamei, A., and Kahmann, R. 2012. Ustilago maydis: Dissecting the molecular interface between pathogen and plant. PLoS Pathog. 8:e1002955. Published online.

Dodds, P. N., Rafiqi, M., Gan, P. H., Hardham, A. R., Jones, D. A., and Ellis, J. G. 2009. Effectors of biotrophic fungi and oomycetes: Pathogenicity factors and triggers of host resistance. New Phytol. 183:9931000

Dong, S., Qutob, D., Tedman-Jones, J., Kuflu, K., Yuanchao, W., Tyler, B. M., and Gijsen, M. 2009. The Phytophthora sojae avirulence locus Avr3c encodes a multi-copy RXLR effector with sequence polymorphisms among pathogen strains. PLoS One 4.Published online.

Dong, S., Yin, W., Kong, G., Yang, X., Qutob, D., Chen, Q., Kale, S. D., Sui, Y., Zhang, Z., Dou, D., Zheng, X., Gijzen, M., Tyler, B., and Wang, Y. 2011a. Phytophthora sojae avirulence effector Avr3b is a secreted NADH and ADP-ribose pyrophosphorylase that modulates plant immunity. PLoS Pathog. 7:e1002353. Published online.

Dong, S., Yu, D., Cui, L., Qutob, D., Tedman-Jones, J., Kale, S. D., Tyler, B. M., Wang, Y., and Gijzen, M. 2011b. Sequence variants of the Phytophthora sojae RXLR effector Avr3a/5 are differentially recognized by Rps3a and Rps5 in soybean. PLoS One 6:e20172. Published online.

Dou, D., Kale, S. D., Wang, X., Chen, Y., Wang, Q., Wang, X., Jiang, R. H Y., Arredondo, F. D., Anderson, R. G., Thakur, P. B., McDowell, J. M., Wang, Y., and Tyler, B. M. 2008a. Conserved C-terminal motifs required for avirulence and suppression of cell death by Phytophthora sojae effector Avr1b. Plant Cell 20:1118-1133.

Dou, D. L., Kale, S. D., Wang, X., Jiang, R. H. Y., Bruce, N. A., Arredondo, F. D., Zhang, X. M., and Tyler, B. M. 2008b. RXLR-mediated entry of Phytophthora sojae effector Avr1b into soybean cells does not require pathogen-encoded machinery. Plant Cell 20:1930-1947.

Dou, D., Kale, S. D., Liu, T., Tang, Q., Wang, X., Arredondo, F. D. Basnayake, S., Whisson, S., Drenth, A., Maclean, D., and Tyler, B. M. 2010. Different domains of Phytophthora sojae effector Avr4/6 are recognized by soybean resistance genes Rps 4 and Rps6. Mol. PlantMicrobe Interact. 23:425-435.

Du, J., Rietman, H., and Vleeshouwers, V. G. A. A. 2013. Agroinfiltration and PVX agroinfection in potato and Nicotiana benthamiana J. Visual. Exp. e50971.

Duplessis, S., Cuomo, C. A., Lin, Y.-C., Aerts, A., Tisserant, E., VeneaultFourrey, C., Joly, D. L., Hacquard, S., Amselem, J., Cantarel, B. L., Chiu, R., Coutinho, P. M., Feau, N., Field, M., Frey, P., Gelhaye, E., Goldberg, J., Grabherr, M. G., Kodira, C. D., Kohler, A., Kües, U., Lindquist, E. A., Lucas, S. M., Mago, R., Mauceli, E., Morin, E., Murat, C., Pangilinan, J. L., Park, R., Pearson, M., Quesneville, H., Rouhier, N., Sakthikumar, S., Salamov, A. A., Schmutz, J., Selles, B., Shapiro, H., Tanguay, P., Tuskan, G. A., Henrissat, B., Van de Peer, Y., Rouzé, P., Ellis, J. G., Dodds, P. N., Schein, J. E., Zhong, S., Hamelin, R. C., Grigoriev, I. V., Szabo, L. J., and Martin, F. 2011. Obligate biotrophy features unraveled by the genomic analysis of rust fungi. Proc. Natl. Acad. Sci. U.S.A. 108:9166-9171.

Effertz, R. J., Meinhardt, S. W., Anderson, J. A., Jordahl, J. G., and Francl, L. J. 2002. Identification of a chlorosis-inducing toxin from Pyrenophora tritici-repentis and the chromosomal location of an insensitivity locus in wheat. Phytopathology 92:527-533.

Egusa, M., Akamatsu, H., Tsuge, T., Otani, H., and Kodama, M. 2008. Induced resistance in tomato plants to the toxin-dependent necrotrophic pathogen Alternaria alternata. Physiol. Mol. Plant Pathol. 73:67-77.

Egusa, M., Ozawa, R., Takabayashi, J., Otani, H., and Kodama, M. 2009. The jasmonate signaling pathway in tomato regulates susceptibility to a toxin-dependent necrotrophic pathogen. Planta 229:965-976.

Ellis, J. G., Dodds, P. N., and Lawrence, G. J. 2007. Flax rust resistance gene specificity is based on direct resistance-avirulence protein interactions. Annu. Rev. Phytopathol. 45:289-306.

Ellis, J. G., Rafiqi, M., Gan, P., Chakrabarti, A., and Dodds, P. N. 2009. Recent progress in discovery and functional analysis of effector proteins of fungal and oomycete plant pathogens. Curr. Opin. Plant Biol. 12:399-405.

Engelhardt, S., Boevink, P. C., Armstrong, M. R., Ramos, M. B., Hein, I., and Birch, P. R. J. 2012. Relocalization of late blight resistance protein $\mathrm{R} 3 \mathrm{a}$ to endosomal compartments is associated with effector recognition and required for the immune response. Plant Cell Online 24:5142-5158.

Erwin, D. C., and Ribiero, O. K. 1996. Phytophthora Diseases Worldwide. American Phytopathological Society Press, St. Paul, MN, U.S.A.

Fabro, G., Steinbrenner, J., Coates, M., Ishaque, N., Baxter, L., Studholme, D. J., Körner, E., Allen, R. L., Piquerez, S. J. M., Rougon-Cardoso, A. Greenshields, D., Lei, R., Badel, J. L., Caillaud, M.-C., Sohn, K.-H., Van den Ackerveken, G., Parker, J. E., Beynon, J., and Jones, J. D. G. 2011. Multiple candidate effectors from the oomycete pathogen Hyaloperonospora arabidopsidis suppress host plant immunity. PLoS Pathog. 7:e1002348. Published online.

Faris, J. D., Zhang, Z., Lu, H., Lu, S., Reddy, L., Cloutier, S., Fellers, J. P., Meinhardt, S. W., Rasmussen, J. B., Xu, S. S., Oliver, R. P., Simons, K. J., and Friesen, T. L. 2010. A unique wheat disease resistance-like gene governs effector-triggered susceptibility to necrotrophic pathogens. Proc. Natl. Acad. Sci. U.S.A. 107:13544-13549.

Faris, J. D., Liu, Z., and Xu, S. S. 2013. Genetics of tan spot resistance in wheat. Theor. Appl. Genet. 126:2197-217.

Farrara, B., Illot, T. W., and Michelmore, R. W. 1987. Genetic analysis of factors for resistance to downy mildew (Bremia lactucae) in lettuce (Lactuca sativa). Plant Pathol. 36:499-514.

Foster, S. J., Park, T. H., Pel, M., Brigneti, G., Sliwka, J., Jagger, L., van der Vossen, E. A. G., and Jones, J. D. G. 2009. Rpi-vnt1.1, a Tm-2(2) homolog from Solanum venturii, confers resistance to potato late blight. Mol. Plant-Microbe Interact. 22:589-600.

Friesen, T. L., Rasmussen, J. B., Kwon, C. Y., Ali, S., Francl, L. J., and Meinhardt, S. W. 2002. Reaction of Ptr ToxA-insensitive wheat mutants to Pyrenophora tritici-repentis race 1. Phytopathology 92:38-42.

Friesen, T. L., Ali, S., Kianian, S., Francl, L. J., and Rasmussen, J. B. 2003. Role of host sensitivity to Ptr ToxA in development of tan spot of wheat. Phytopathology 93:397-401.

Friesen, T. L., Stukenbrock, E. H., Liu, Z., Meinhardt, S., Ling, H., Faris, J. D., Rasmussen, J. B., Solomon, P. S., McDonald, B. A., and Oliver, R. P. 2006. Emergence of a new disease as a result of interspecific virulence gene transfer. Nat. Genet. 38:953-956.

Friesen, T. L., Chu, C. G., Liu, Z. H., Xu, S. S., Halley, S., and Faris, J. D. 2009. Host-selective toxins produced by Stagonospora nodorum confer disease susceptibility in adult wheat plants under field conditions. Theor. Appl. Genet. 118:1489-1497.

Fry, W. E. 2008. Phytophthora infestans: The plant (and $R$ gene) destroyer Mol. Plant Pathol. 9:385-402.

Gao, H., and Bhattacharyya, M. K. 2008. The soybean-Phytophthora resistance locus Rps $1-k$ encompasses coiled coil-nucleotide bindingleucine rich repeat-like genes and repetitive sequences. BMC Plant Biol. 8:Nil_1-Nil_14.

Gengenbach, B. G., Green, C. E., and Donovan, C. M. 1977. Inheritance of selected pathotoxin resistance in maize plants regenerated from cell cultures. Proc. Natl. Acad. Sci. U.S.A. 74:5113-5117.

Gilroy, E. M., Breen, S., Whisson, S. C., Squires, J., Hein, I., Kaczmarek, M., Turnbull, D., Boevink, P. C., Lokossou, A., Cano, L. M., Morales, J., Avrova, A. O., Pritchard, L., Randall, E., Lees, A., Govers, F., van West, P., Kamoun, S., Vleeshouwers, V. G. A. A., Cooke, D. E. L., and Birch, P. R. J. 2011. Presence/absence, differential expression and sequence polymorphisms between PiAVR2 and PiAVR2-like in Phytophthora infestans determine virulence on $R 2$ plants. New Phytol. 191:763776.

Goritschnig, S., Krasileva, K. V., Dahlbeck, D., and Staskawicz, B. J. 2012. Computational prediction and molecular characterization of an oomycete effector and the cognate Arabidopsis resistance gene. PLoS Genet. 8. Published online.

Haas, B. J., Kamoun, S., Zody, M. C., Jiang, R. H., Handsaker, R. E., Cano, L. M., Grabherr, M., Kodira, C. D., Raffaele, S., Torto-Alalibo, T., Bozkurt, T. O., Ah-Fong, A. M., Alvarado, L., Anderson, V. L., Armstrong, M. R., Avrova, A., Baxter, L., Beynon, J., Boevink, P. C., 
Bollmann, S. R., Bos, J. I., Bulone, V., Cai, G., Cakir, C., Carrington, J. C., Chawner, M., Conti, L., Costanzo, S., Ewan, R., Fahlgren, N., Fischbach, M. A., Fugelstad, J., Gilroy, E. M., Gnerre, S., Green, P. J., Grenville-Briggs, L. J., Griffith, J., Grunwald, N. J., Horn, K., Horner, N. R., Hu, C. H., Huitema, E., Jeong, D. H., Jones, A. M., Jones, J. D., Jones, R. W., Karlsson, E. K., Kunjeti, S. G., Lamour, K., Liu, Z., Ma, L., Maclean, D., Chibucos, M. C., McDonald, H., McWalters, J., Meijer, H. J., Morgan, W., Morris, P. F., Munro, C. A., O'Neill, K., Ospina-Giraldo, M., Pinzon, A., Pritchard, L., Ramsahoye, B., Ren, Q., Restrepo, S., Roy, S., Sadanandom, A., Savidor, A., Schornack, S., Schwartz, D. C., Schumann, U. D., Schwessinger, B., Seyer, L., Sharpe, T., Silvar, C., Song, J., Studholme, D. J., Sykes, S., Thines, M., van de Vondervoort, P. J., Phuntumart, V., Wawra, S., Weide, R., Win, J., Young, C., Zhou, S., Fry, W., Meyers, B. C., van West, P., Ristaino, J., Govers, F., Birch, P. R., Whisson, S. C., Judelson, H. S., and Nusbaum, C. 2009. Genome sequence and analysis of the Irish potato famine pathogen Phytophthora infestans. Nature 461:393-398.

Hammond-Kosack, K. E., and Rudd, J. J. 2008. Plant resistance signalling hijacked by a necrotrophic fungal pathogen. Plant Signal. Behav. 3:993995.

Hane, J. K., Lowe, R. G., Solomon, P. S., Tan, K. C., Schoch, C. L., Spatafora, J. W., Crous, P. W., Kodira, C., Birren, B. W., Galagan, J. E., Torriani, S. F., McDonald, B. A., and Oliver, R. P. 2007. Dothideomycete plant interactions illuminated by genome sequencing and EST analysis of the wheat pathogen Stagonospora nodorum. Plant Cell 19:3347-3368.

Harimoto, Y., Tanaka, T., Kodama, M., Yamamoto, M., Otani, H., and Tsuge, T. 2008. Multiple copies of AMT2 are prerequisite for the apple pathotype of Alternaria alternata to produce enough AM-toxin for expressing pathogenicity. J. Gen. Plant Pathol. 74:222-229.

Hatta, R., Ito, K., Hosaki, Y., Tanaka, T., Tanaka, A., Yamamoto, M., Akimitsu, K., and Tsuge, T. 2002. A conditionally dispensable chromosome controls host-specific pathogenicity in the fungal plant pathogen Alternaria alternata. Genetics 161:59-70.

Hein, I., Gilroy, E. M., Armstrong, M. R., and Birch, P. R. J. 2009. The zig-zag-zig in oomycete-plant interactions. Mol. Plant Pathol. 10:547562 .

Hermsen, J. G. T., and Ramanna, M. S. 1973. Double-bridge hybrids of Solanum bulbocastanum and cultivars of Solanum tuberosum. Euphytica 22:457-466.

Hogenhout, S. A., Van der Hoorn, R. A., Terauchi, R., and Kamoun, S. 2009. Emerging concepts in effector biology of plant-associated organisms. Mol. Plant-Microbe Interact. 22:115-122.

Huang, S., van der Vossen, E. A. G., Kuang, H., Vleeshouwers, V. G. A A., Zhang, N., Borm, T. J. A., van Eck, H. J., Baker, B., Jacobsen, E., and Visser, R. G. F. 2005. Comparative genomics enabled the isolation of the $R 3 a$ late blight resistance gene in potato. Plant J. 42:251-261.

Jiang, R. H., Tripathy, S., Govers, F., and Tyler, B. M. 2008. RXLR effector reservoir in two Phytophthora species is dominated by a single rapidly evolving superfamily with more than 700 members. Proc. Natl. Acad. Sci. U.S.A. 105:4874-4879.

Jiang, R. H. Y., Weide, R., de Vondervoort, P., and Govers, F. 2006. Amplification generates modular diversity at an avirulence locus in the pathogen Phytophthora. Genome Res. 16:827-840.

Johal, G. S., and Briggs, S. P. 1992. Reductase activity encoded by the HM1 disease resistance gene in maize. Science 258:985-987.

Johnson, L. J., Johnson, R. D., Akamatsu, H., Salamiah, A., Otani, H., Kohmoto, K., and Kodama, M. 2001. Spontaneous loss of a conditionally dispensable chromosome from the Alternaria alternata apple pathotype leads to loss of toxin production and pathogenicity. Curr. Genet. 40:65-72.

Jones, J. D. G., and Dangl, J. L. 2006. The plant immune system. Nature 444:323-329

Judelson, H. S., Ah-Fong, A. M. V., Aux, G., Avrova, A. O., Bruce, C., Cakir, C., Da Cunha, L., Grenville-Briggs, L., Latijnhouwers, M., Ligterink, W., Meijer, H. J. G., Roberts, S., Thurber, C. S., Whisson, S. C., Birch, P. R. J., Govers, F., Kamoun, S., Van West, P., and Windass, J. 2008. Gene expression profiling during asexual development of the late blight pathogen Phytophthora infestans reveals a highly dynamic transcriptome. Mol. Plant-Microbe Interact. 21:433-447.

Jupe, F., Pritchard, L., Etherington, G., MacKenzie, K., Cock, P., Wright, F., Sharma, S. K., Bolser, D., Bryan, G., Jones, J., and Hein, I. 2012. Identification and localisation of the NB-LRR gene family within the potato genome. BMC Genomics 13:75.

Kamoun, S. 2003. Molecular genetics of pathogenic oomycetes. Eukaryot. Cell 2:191-199.

Kamoun, S., Van West, P., De Jong, A. J., De Groot, K. E., Vleeshouwers, V. G. A. A., and Govers, F. 1997. A gene encoding a protein elicitor of Phytophthora infestans is down-regulated during infection of potato. Mol. Plant-Microbe Interact. 10:13-20.
Kamoun, S., Hraber, P., Sobral, B., Nuss, B., and Govers, F. 1999. Initial assessment of gene diversity for the oomycete pathogen Phytophthora infestans based on expressed sequences. Fungal Genet. Biol. 28:94-106.

Kamoun, S., Segretin, M. E., and Schornack, S. July 2012. Late blight resistance genes. Patent number WO 2013/009935 A2

Kanneganti, T. D., Huitema, E., Cakir, C., and Kamoun, S. 2006. Synergistic interactions of the plant cell death pathways induced by Phytoph thora infestans Nep1-like protein PiNPP1.1 and INF1 elicitin. Mol. Plant-Microbe Interact. 19:854-863.

Keon, J., Antoniw, J., Carzaniga, R., Deller, S., Ward, J. L., Baker, J. M., Beale, M. H., Hammond-Kosack, K., and Rudd, J. J. 2007. Transcriptional adaptation of Mycosphaerella graminicola to programmed cell death (PCD) of Its susceptible wheat host. Mol. Plant-Microbe Interact. 20:178-193.

Kim, H.-J., Lee, H.-R., Kwang-Ryong, J., Mortazavian, S. M. M., Huigen, D. J., Evenhuis, B., Kessel, G., Visser, R. G. F., Jacobsen, E., and Vossen, J. H. 2011. Broad spectrum late blight resistance in potato differential set plants MaR8 and MaR9 is conferred by multiple stacked $R$ genes. Theor. Appl. Genet. 124:923-935.

Kunjeti, S. G., Evans, T. A., Marsh, A. G., Gregory, N. F., Kunjeti, S., Meyers, B. C., Kalavacharla, V. S., and Donofrio, N. M. 2011. RNASeq reveals infection-related global gene changes in Phytophthora phaseoli, the causal agent of lima bean downy mildew. Mol. Plant Pathol. 13:454-466.

Kwang-Ryong, J. 2013. Unveiling and deploying durability of late blight resistance in potato. Ph.D. thesis, Wageningen University, Wageningen, The Netherlands.

Kwang-Ryong, J., Arens, M., Kim, T.-Y., Jongsma, M., Visser, R., Jacobsen, E., and Vossen, J. 2011. Mapping of the S. demissum late blight resistance gene $R 8$ to a new locus on chromosome IX. TAG Theor. Appl. Genet. 123:1331-1340.

Lacombe, S., Rougon-Cardoso, A., Sherwood, E., Peeters, N., Dahlbeck, D., van Esse, H. P., Smoker, M., Rallapalli, G., Thomma, B. P. H. J., Staskawicz, B., Jones, J. D. G., and Zipfel, C. 2010. Interfamily transfer of a plant pattern-recognition receptor confers broad-spectrum bacterial resistance. Nat. Biotechnol. 28:365-369.

Laugé, R., Joosten, M. H. A. J., Haanstra, J. P., Goodwin, P. H., Lindhout, P., and de Wit, P. J. G. M. 1998. Successful search for a resistance gene in tomato targeted against a virulence factor of a fungal pathogen. Proc. Natl. Acad. Sci. U.S.A. 95:9014-9018.

Levesque, C. A., Brouwer, H., Cano, L., Hamilton, J. P., Holt, C., Huitema, E., Raffaele, S., Robideau, G. P., Thines, M., Win, J., Zerillo, M. M., Beakes, G. W., Boore, J. L., Busam, D., Dumas, B., Ferriera, S., Fuerstenberg, S. I., Gachon, C. M. M., Gaulin, E., Govers, F., GrenvilleBriggs, L., Horner, N., Hostetler, J., Jiang, R. H. Y., Johnson, J., Krajaejun, T., Lin, H., Meijer, H. J. G., Moore, B., Morris, P., Phuntmart, V., Puiu, D., Shetty, J., Stajich, J. E., Tripathy, S., Wawra, S., van West, P., Whitty, B. R., Coutinho, P. M., Henrissat, B., Martin, F., Thomas, P. D., Tyler, B. M., De Vries, R. P., Kamoun, S., Yandell, M., Tisserat, N., and Buell, C. R. 2010. Genome sequence of the necrotrophic plant pathogen, Pythium ultimum, reveals original pathogenicity mechanisms and effector repertoire. Genome Biol. 11.R73. Published online.

Li, G., Huang, S., Guo, X., Li, Y., Yang, Y., Guo, Z., Kuang, H., Rietman, H., Bergervoet, M., Vleeshouwers, V. G. A. A., van der Vossen, E. A. G., Qu, D.-Y., Visser, R. G. F., Jacobsen, E., and Vossen, J. 2011. Cloning and characterization of $R 3 b$; Members of the $R 3$ superfamily of late blight resistance genes show sequence and functional divergence. Mol. Plant-Microbe Interact. 24:1132-1142.

Links, M. G., Holub, E., Jiang, R. H. Y., Sharpe, A. G., Hegedus, D., Beynon, E., Sillito, D., Clarke, W. E., Uzuhashi, S., and Borhan, M. H. 2011. De novo sequence assembly of Albugo candida reveals a small genome relative to other biotrophic oomycetes. BMC Genomics 12:503. Published online.

Liu, Z., Friesen, T. L., Ling, H., Meinhardt, S. W., Oliver, R. P., Rasmussen, J. B., and Faris, J. D. 2006. The Tsn1-ToxA interaction in the wheatStagonospora nodorum pathosystem parallels that of the wheat-tan spot system. Genome 49:1265-1273.

Liu, Z., Faris, J. D., Oliver, R. P., Tan, K. C., Solomon, P. S., McDonald, M. C., McDonald, B. A., Nunez, A., Lu, S., Rasmussen, J. B., and Friesen, T. L. 2009. SnTox3 acts in effector triggered susceptibility to induce disease on wheat carrying the Snn3 gene. PLoS Pathog. 5:e1000581. Published online.

Liu, Z., Zhang, Z., Faris, J. D., Oliver, R. P., Syme, R., McDonald, M. C., McDonald, B. A., Solomon, P. S., Lu, S., Shelver, W. L., Xu, S., and Friesen, T. L. 2012. The cysteine rich necrotrophic effector SnTox1 produced by Stagonospora nodorum triggers susceptibility of wheat lines harboring Snn1. PLoS Pathog. 8. Published online.

Liu, Z. H., Faris, J. D., Meinhardt, S. W., Ali, S., Rasmussen, J. B., and Friesen, T. L. 2004. Genetic and physical mapping of a gene conditioning sensitivity in wheat to a partially purified host-selective toxin pro- 
duced by Stagonospora nodorum. Phytopathology 94:1056-1060.

Lokossou, A. A., Park, T. H., van Arkel, G., Arens, M., Ruyter-Spira, C., Morales, J., Whisson, S. C., Birch, P. R. J., Visser, R. G. F., Jacobsen, E., and van der Vossen, E. A. G. 2009. Exploiting knowledge of $R / A v r$ genes to rapidly clone a new LZ-NBS-LRR family of late blight resistance genes from potato linkage group IV. Mol. Plant-Microbe Interact. 22:630-641.

Lokossou, A. A., Rietman, H., Wang, M., Krenek, P., van der Schoot, H., Henken, B., Hoekstra, R., Vleeshouwers, V. G. A. A., van der Vossen, E. A. G., Visser, R. G. F., Jacobsen, E., and Vosman, B. 2010. Diversity, distribution, and evolution of Solanum bulbocastanum late blight resistance genes. Mol. Plant-Microbe Interact. 23:1206-1216.

Lorang, J. M., Sweat, T. A., and Wolpert, T. J. 2007. Plant disease susceptibility conferred by a "resistance" gene. Proc. Natl. Acad. Sci. U.S.A. 104:14861-14866.

Manning, V. A., Chu, A. L., Steeves, J. E., Wolpert, T. J., and Ciuffetti, L. M. 2009. A host-selective toxin of Pyrenophora tritici-repentis, Ptr ToxA, induces photosystem changes and reactive oxygen species accumulation in sensitive wheat. Mol. Plant-Microbe Interact. 22:665-676.

Masuda, T., Yoshioka, T., Inoue, K., Murata, K., Kitagawa, K., Tabira, H., Yoshida, A., Kotobuki, K., and Sanada, T. 1997. Selection of mutants resistant to black spot disease by chronic irradiation of gamma-rays in Japanese pear 'Osanijisseiki'. J. Jpn. Soc. Hortic. Sci. 66:85-92.

McDonald, M. C., Oliver, R. P., Friesen, T. L., Brunner, P. C., and McDonald, B. A. 2013. Global diversity and distribution of three necrotrophic effectors in Phaeosphaeria nodorum and related species. New Phytol. 199:241-251.

Miyamoto, Y., Masunaka, A., Tsuge, T., Yamamoto, M., Ohtani, K., Fukumoto, T., Gomi, K., Peever, T. L., and Akimitsu, K. 2008. Functional analysis of a multicopy host-selective ACT-toxin biosynthesis gene in the tangerine pathotype of Alternaria alternata using RNA silencing. Mol. Plant-Microbe Interact. 21:1591-1599.

Miyamoto, Y., Ishii, Y., Honda, A., Masunaka, A., Tsuge, T., Yamamoto, M., Ohtani, K., Fukumoto, T., Gomi, K., Peever, T. L., and Akimitsu, K. 2009. Function of genes encoding acyl-CoA synthetase and enoyl-CoA hydratase for host-selective ACT-toxin biosynthesis in the tangerine pathotype of Alternaria alternata. Phytopathology 99:369-377.

Murray, G. M., and Brennan, J. P. 2009. Estimating disease losses to the Australian wheat industry. Australas. Plant Pathol. 38:558-570.

Na, R., Yu, D., Qutob, D., Zhao, J., and Gijzen, M. 2013. Deletion of the Phytophthora sojae avirulence gene Avrld causes gain of virulence on Rps1d. Mol. Plant-Microbe Interact. 26:969-976.

Navarre, D. A., and Wolpert, T. J. 1995. Inhibition of the glycine decarboxylase multienzyme complex by the host-selective toxin victorin. Plant Cell 7:463-471.

Nekrasov, V., Staskawicz, B., Weigel, D., Jones, J. D. G., and Kamoun, S. 2013. Targeted mutagenesis in the model plant Nicotiana benthamiana using Cas9 RNA-guided endonuclease. Nat. Biotechnol. 31:691-693.

Oh, S.-K., Young, C., Lee, M., Oliva, R., Bozkurt, T. O., Cano, L. M., Win, J., Bos, J. I. B., Liu, H.-Y., van Damme, M., Morgan, W., Choi, D., Van der Vossen, E. A. G., Vleeshouwers, V. G. A. A., and Kamoun, S. 2009. In planta expression screens of Phytophthora infestans RXLR effectors reveal diverse phenotypes, including activation of the Solanum bulbocastanum disease resistance protein Rpi-blb2. Plant Cell 21:29282947.

Oliver, R. 2012. Genomic tillage and the harvest of fungal phytopathogens. New Phytol. 196:1015-1023.

Oliver, R. P., and Solomon, P. S. 2010. New developments in pathogenicity and virulence of necrotrophs. Curr. Opin. Plant Biol. 13:415-419.

Oliver, R. P., Friesen, T. L., Faris, J. D., and Solomon, P. S. 2012. Stagonospora nodorum: From pathology to genomics and host resistance. Annu. Rev. Phytopathol. 50:23-43.

Pais, M., Win, J., Yoshida, K., Etherington, G., Cano, L., Raffaele, S., Banfield, M., Jones, A., Kamoun, S., and Saunders, D. G. O. 2013. From pathogen genomes to host plant processes: The power of plant parasitic oomycetes. Genome Biol. 14:211.

Pel, M. A. 2010. Mapping, isolation and characterization of genes responsible for late blight resistance in potato. Ph.D. thesis, Wageningen University, Wageningen, The Netherlands.

Pel, M. A., Foster, S. J., Park, T. H., Rietman, H., van Arkel, G., Jones, J. D., Van Eck, H. J., Jacobsen, E., Visser, R. G. F., and van der Vossen, E. A. G. 2009. Mapping and cloning of late blight resistance genes from Solanum venturii using an interspecific candidate gene approach. Mol. Plant-Microbe Interact. 22:601-615.

Quinn, L., O’Neill, P. A., Harrison, J., Paskiewicz, K. H., McCracken, A. R., Cooke, L. R., Grant, M. R., and Studholme, D. J. 2013. Genomewide sequencing of Phytophthora lateralis reveals genetic variation among isolates from Lawson cypress (Chamaecyparis lawsoniana) in Northern Ireland. FEMS (Fed. Eur. Microbiol. Soc.) Microbiol. Lett. 344:179-185.
Qutob, D., Hraber, P. T., Sobral, B. W. S., and Gijzen, M. 2000. Comparative analysis of expressed sequences in Phytophthora sojae. Plant Physiol. 123:243-253.

Qutob, D., Kamoun, S., and Gijzen, M. 2002. Expression of a Phytophthora sojae necrosis-inducing protein occurs during transition from biotrophy to necrotrophy. Plant J. 32:361-373.

Qutob, D., Tedman-Jones, J., Dong, S., Kuflu, K., Pham, H., Wang, Y., Dou, D., Kale, S. D., Arredondo, F. D., Tyler, B. M., and Gijzen, M. 2009. Copy number variation and transcriptional polymorphisms of Phytophthora sojae RXLR effector genes Avrla and Avr3a. PLoS One 4. Published online.

Raffaele, S., Farrer, R. A., Cano, L. M., Studholme, D. J., MacLean, D., Thines, M., Jiang, R. H. Y., Zody, M. C., Kunjeti, S. G., Donofrio, N. M., Meyers, B. C., Nusbaum, C., and Kamoun, S. 2010. Genome evolution following host jumps in the Irish potato famine pathogen lineage. Science 330:1540-1543.

Randall, T. A., Dwyer, R. A., Huitema, E., Beyer, K., Cvitanich, C., Kelkar, H., Fong, A., Gates, K., Roberts, S., Yatzkan, E., Gaffney, T., Law, M., Testa, A., Torto Alalibo, T., Zhang, M., Zheng, L., Mueller, E., Windass, J., Binder, A., Birch, P. R. J., Gisi, U., Govers, F., Gow, N. A., Mauch, F., van West, P., Waugh, M. E., Yu, J., Boller, T., Kamoun, S., Lam, S. T., and Judelson, H. S. 2005. Large-scale gene discovery in the oomycete Phytophthora infestans reveals likely components of phytopathogenicity shared with true fungi. Mol. Plant-Microbe Interact. 18:229243.

Rentel, M. C., Leonelli, L., Dahlbeck, D., Zhao, B., and Staskawicz, B. J. 2008. Recognition of the Hyaloperonospora parasitica effector ATR13 triggers resistance against oomycete, bacterial, and viral pathogens. Proc. Natl. Acad. Sci. U.S.A. 105:1091-1096.

Ridout, C. J., Skamnioti, P., Porritt, O., Sacristan, S., Jones, J. D., and Brown, J. K. 2006. Multiple avirulence paralogues in cereal powdery mildew fungi may contribute to parasite fitness and defeat of plant resistance. Plant Cell 18:2402-2414.

Rietman, H. 2011. Putting the Phytophthora infestans genome sequence at work; multiple novel avirulence and potato resistance gene candidates revealed. Ph.D. thesis, Wageningen University, Wageningen, The Netherlands.

Rietman, H., Bijsterbosch, G., Cano, L. M., Lee, H. R., Vossen, J. H., Jacobsen, E., Visser, R. G. F., Kamoun, S., and Vleeshouwers, V. G. A A. 2012. Qualitative and quantitative late blight resistance in the potato cultivar Sarpo Mira is determined by the perception of five distinct RXLR effectors. Mol. Plant-Microbe Interact. 25:910-919.

Rines, H., and Luke, H. H. 1985. Selection and regeneration of toxininsensitive plants from tissue cultures of oats (Avena sativa) susceptible to Helminthsporium victoriae. Theor. Appl. Genet. 71:16-21.

Rohe, M., Gierlich, A., Hermann, H., Hahn, M., Schmidt, B., Rosahl, S., and Knogge, W. 1995. The race-specific elicitor, NIP1, from the barley pathogen, Rhynchosporium secalis, determines avirulence on host plants of the Rrs 1 resistance genotype. EMBO (Eur. Mol. Biol. Organ.) J. 14:4168-4177.

Rudd, J. J., Antoniw, J., Marshall, R., Motteram, J., Fraaije, B., and Hammond-Kosack, K. 2010. Identification and characterisation of Mycosphaerella graminicola secreted or surface-associated proteins with variable intragenic coding repeats. Fungal Genet. Biol. 47:19-32.

Saito, A., Nakazawa, N., and Suzuki, M. 2001. Selection of mutants resistant to Alternaria blotch from in vitro-cultured apple shoots irradiated with X- and gamma-rays. J. Plant Physiol. 158:391-400.

Sandhu, D., Gao, H., Cianzio, S., and Bhattacharyya, M. K. 2004. Deletion of a disease resistance nucleotide-binding-site leucine-rich-repeatlike sequence is associated with the loss of the Phytophthora resistance gene Rps4 in soybean. Genetics 168:2157-2167.

Saunders, D. G. O., Breen, S., Win, J., Schornack, S., Hein, I., Bozkurt, T. O., Champouret, N., Vleeshouwers, V. G. A. A., Birch, P. R. J., Gilroy, E. M., and Kamoun, S. 2012a. Host protein BSL1 associates with Phytophthora infestans RXLR effector AVR2 and the Solanum demissum immune receptor R2 to mediate disease resistance. Plant Cell 24:34203434.

Saunders, D. G. O., Win, J., Cano, L. M., Szabo, L. J., Kamoun, S., and Raffaele, S. 2012b. Using hierarchical clustering of secreted protein families to classify and rank candidate effectors of rust fungi. PLoS One 7:e29847. Published online.

Savory, E. A., Adhikari, B. N., Hamilton, J. P., Vaillancourt, B., Buell, C. R., and Day, B. 2012. mRNA-seq analysis of the Pseudoperonospora cubensis transcriptome during cucumber (Cucumis sativus L.) infection. PLoS One 7. Published online.

Schouten, H. J., Krens, F. A., and Jacobsen, E. 2006. Cisgenic plants are similar to traditionally bred plants: International regulations for genetically modified organisms should be altered to exempt cisgenesis. EMBO (Eur. Mol. Biol. Organ.) Rep. 7:750-753.

Schurch, S., Linde, C. C., Knogge, W., Jackson, L. F., and McDonald, B. 
A. 2004. Molecular population genetic analysis differentiates two virulence mechanisms of the fungal avirulence gene NIP1. Mol. PlantMicrobe Interact. 17:1114-1125.

Shan, W. X., Cao, M., Leung, D., and Tyler, B. M. 2004. The Avr1b locus of Phytophthora sojae encodes an elicitor and a regulator required for avirulence on soybean plants carrying resistance gene Rps $1 b$. Mol. Plant-Microbe Interact. 17:394-403.

Sharma, S., Hirabuchi, A., Yoshida, K., Fujisaki, K., Ito, A., Uemura, A., Terauchi, R., Kamoun, S., Sohn, K. H., Jones, J. D., and Saitoh, H. 2013. Deployment of the Burkholderia glumae type III secretion system as an efficient tool for translocating pathogen effectors to monocot cells. Plant J. 74:701-712.

Singh, R. P., Hodson, D. P., Huerta-Espino, J., Jin, Y., Bhavani, S., Njau, P., Herrera-Foessel, S., Singh, P. K., Singh, S., and Govindan, V. 2011. The emergence of Ug99 races of the stem rust fungus is a threat to world wheat production. Annu. Rev. Phytopathol. 49:465-481.

Sohn, K. H., Lei, R., Nemri, A., and Jones, J. D. 2007. The downy mildew effector proteins ATR1 and ATR13 promote disease susceptibility in Arabidopsis thaliana. Plant Cell 19:4077-4090.

Song, J., Bradeen, J. M., Naess, S. K., Raasch, J. A., Wielgus, S. M., Haberlach, G. T., Liu, J., Kuang, H., Austin-Phillips, S., Buell, C. R., Helgeson, J. P., and Jiang, J. 2003. Gene RB cloned from Solanum bulbocastanum confers broad spectrum resistance to potato late blight. Proc. Natl. Acad. Sci. U.S.A. 100:9128-9133.

Song, T., Kale, S. D., Arredondo, F. D., Shen, D., Su, L., Liu, L., Wu, Y. Wang, Y., Dou, D., and Tyler, B. M. 2013. Two RxLR avirulence genes in Phytophthora sojae determine soybean Rps $1 k$-mediated disease resistance. Mol. Plant-Microbe Interact. 26:711-720.

Staats, M., van Baarlen, P., Schouten, A., van Kan, J. A. L., and Bakker, F. T. 2007. Positive selection in phytotoxic protein-encoding genes of Botrytis species. Fungal Genet. Biol. 44:52-63.

Stassen, J., den Boer, E., Vergeer, P. W. J., Andel, A., Ellendorff, U., Pelgrom, K., Pel, M., Schut, J., Zonneveld, O., Jeuken, M. J. W., and Van den Ackerveken, G. 2013. Specific in planta recognition of two GKLR proteins of the downy mildew Bremia lactucae revealed in a large effector screen in lettuce. Mol. Plant-Microbe Interact. 26:12591270 .

Stassen, J. H. M., Seidl, M. F., Vergeer, P. W. J., Nijman, I. J., Snel, B., Cuppen, E., and Van Den Ackerveken, G. 2012. Effector identification in the lettuce downy mildew Bremia lactucae by massively parallel transcriptome sequencing. Mol. Plant Pathol. 13:719-731.

Sweat, T. A., Lorang, J. M., Bakker, E. G., and Wolpert, T. J. 2008. Characterization of natural and induced variation in the LOV1 gene, a CCNB-LRR gene conferring victorin sensitivity and disease susceptibility in Arabidopsis. Mol. Plant-Microbe Interact. 21:7-19.

Tanaka, A., and Tsuge, T. 2000. Structural and functional complexity of the genomic region controlling AK-toxin biosynthesis and pathogenicity in the Japanese pear pathotype of Alternaria alternata. Mol. PlantMicrobe Interact. 13:975-986.

Tatum, L. A. 1971. The Southern corn leaf blight epidemic. Science 171:1113-1116.

Thomas, W. J., Thireault, C. A., Kimbrel, J. A., and Chang, J. H. 2009. Recombineering and stable integration of the Pseudomonas syringae pv. syringae $61 \mathrm{hrp} / \mathrm{hrc}$ cluster into the genome of the soil bacterium Pseudomonas fluorescens Pf0-1. Plant J. 60:919-928.

Tiemens-Hulscher, M., Delleman, J., Eising, J., and Lammerts Van Bueren, E. T. 2013. Potato Breeding: A Practical Manual for the Potato Chain. De Swart, The Hague, The Netherlands.

Torto, T. A., Li, S. A., Styer, A., Huitema, E., Testa, A., Gow, N. A. R., van West, P., and Kamoun, S. 2003. EST mining and functional expression assays identify extracellular effector proteins from the plant pathogen Phytophthora. Genome Res. 13:1675-1685.

Tsuge, T., Harimoto, Y., Akimitsu, K., Ohtani, K., Kodama, M., Akagi, Y., Egusa, M., Yamamoto, M., and Otani, H. 2013. Host-selective toxins produced by the plant pathogenic fungus Alternaria alternata. FEMS (Fed. Eur. Microbiol. Soc.) Microbiol. Rev. 37:44-66.

Tyler, B. M. 2009. Effectors. Pages 361-386 in: Oomycete Genetics and Henomics; Diversity, Interactions, and Research Tools. Wiley-Blackwell, Hoboken, NJ, U.S.A.

Tyler, B. M., Tripathy, S., Zhang, X. M., Dehal, P., Jiang, R. H. Y., Aerts, A., Arredondo, F. D., Baxter, L., Bensasson, D., Beynon, J. L., Chapman, J., Damasceno, C. M. B., Dorrance, A. E., Dou, D. L., Dickerman, A. W., Dubchak, I. L., Garbelotto, M., Gijzen, M., Gordon, S. G., Govers, F., Grunwald, N. J., Huang, W., Ivors, K. L., Jones, R. W., Kamoun, S., Krampis, K., Lamour, K. H., Lee, M. K., McDonald, W. H., Medina, M., Meijer, H. J. G., Nordberg, E. K., Maclean, D. J., Ospina Giraldo, M. D., Morris, P. F., Phuntumart, V., Putnam, N. H., Rash, S., Rose, J.
K. C., Sakihama, Y., Salamov, A. A., Savidor, A., Scheuring, C. F. Smith, B. M., Sobral, B. W. S., Terry, A., Torto Alalibo, T. A., Win, J., Xu, Z. Y., Zhang, H. B., Grigoriev, I. V., Rokhsar, D. S., and Boore, J. L. 2006. Phytophthora genome sequences uncover evolutionary origins and mechanisms of pathogenesis. Science 313:1261-1266.

Upadhyaya, N. M., Mago, R., Staskawicz, B. J., Ayliffe, M. A., Ellis, J. G., and Dodds, P. N. 2014. A bacterial type III secretion assay for delivery of fungal effector proteins into wheat. Mol. Plant-Microbe Interact. 27:255-264.

van der Hoorn, R. A., and Kamoun, S. 2008. From guard to decoy: A new model for perception of plant pathogen effectors. Plant Cell 20:20092017

van der Lee, T., Testa, A., van' t Klooster, J., van den Berg Velthuis, G., and Govers, F. 2001. Chromosomal deletion in isolates of Phytophthora infestans correlates with virulence on $R 3, R 10$, and $R 11$ potato lines. Mol. Plant-Microbe Interact. 14:1444-1452.

van der Vossen, E., Sikkema, A., te Lintel Hekkert, B., Gros, J., Stevens, P., Muskens, M., Wouters, D., Pereira, A., Stiekema, W., and Allefs, S. 2003. An ancient $R$ gene from the wild potato species Solanum bulbocastanum confers broad-spectrum resistance to Phytophthora infestans in cultivated potato and tomato. Plant J. 36:867-882.

van der Vossen, E. A. G., Gros, J., Sikkema, A., Muskens, M., Wouters, D., Wolters, P., Pereira, A., and Allefs, S. 2005. The Rpi-blb2 gene from Solanum bulbocastanum is an $\mathrm{Mi}-1$ gene homolog conferring broadspectrum late blight resistance in potato. Plant J. 44:208-222.

van Poppel, P. M. J. A., Guo, J., van de Vondervoort, P. J., Jung, M. W., Birch, P. R., Whisson, S. C., and Govers, F. 2008. The Phytophthora infestans avirulence gene Avr4 encodes an RXLR-dEER effector. Mol. Plant-Microbe Interact. 21:1460-1470.

Vleeshouwers, V., Rietman, H., Krenek, P., Champouret, N., Young, C., Oh, S.-K., Wang, M., Bouwmeester, K., Vosman, B., and Visser, R. 2008. Effector genomics accelerates discovery and functional profiling of potato disease resistance and Phytophthora infestans avirulence genes. PLoS One 3:e2875. Published online.

Vleeshouwers, V. G. A. A., Finkers, R., Budding, D. J., Visser, M., Jacobs, M. M. J., van Berloo, R., Pel, M., Champouret, N., Bakker, E., Krenek, P., Rietman, H., Huigen, D. J., Hoekstra, R., Goverse, A., Vosman, B., Jacobsen, E., and Visser, R. G. F. 2011a. SolRgene: An online database to explore disease resistance genes in tuber-bearing Solanum species. BMC Plant Biol. 11. Published online.

Vleeshouwers, V. G. A. A., Raffaele, S., Vossen, J., Champouret, N., Oliva, R., Segretin, M. E., Rietman, H., Cano, L. M., Lokossou, A. A., Kessel, G. J. T., Pel, M., and Kamoun, S. 2011b. Understanding and exploiting late blight resistance in the age of effectors. Annu. Rev. Phytopathol. 49:507-531.

Walton, J. D. 2006. HC-toxin. Phytochemistry 67:1406-1413.

Wastie, R. 1991. Breeding for resistance. Pages 193-224 in: Phytophthora infestans, the Cause of Late Blight of Potato. D. Ingram and P. Williams, eds. Academic Press, London.

Whisson, S. C., Boevink, P. C., Moleleki, L., Avrova, A. O., Morales, J. G., Gilroy, E. M., Armstrong, M. R., Grouffaud, S., van West, P., Chapman, S., Hein, I., Toth, I. K., Pritchard, L., and Birch, P. R. J. 2007. A translocation signal for delivery of oomycete effector proteins into host plant cells. Nature 450:115-118.

Win, J., Morgan, W., Bos, J., Krasileva, K. V., Cano, L. M., ChaparroGarcia, A., Ammar, R., Staskawicz, B. J., and Kamoun, S. 2007. Adaptive evolution has targeted the C-terminal domain of the RXLR effectors of plant pathogenic oomycetes. Plant Cell 19:2349-2369.

Wolpert, T. J., Dunkle, L. D., and Ciuffetti, L. M. 2002. Host-selective toxins and avirulence determinants: What's in a name? Annu. Rev. Phytopathol. 40:251-285

Yakimova, E. T., Yordanova, Z. P., Slavov, S., Kapchina-Toteva, V. M., and Woltering, E. J. 2009. Alternaria alternata at toxin induces programmed cell death in tobacco. J. Phytopathol. 157:592-601.

Ye, W., Wang, X., Tao, K., Lu, Y., Dai, T., Dong, S., Dou, D., Gijzen, M., and Wang, Y. 2011. Digital gene expression profiling of the Phytophthora sojae transcriptome. Mol. Plant-Microbe Interact. 24:15301539

Yin, W., Dong, S., Zhai, L., Lin, Y., Zheng, X., and Wang, Y. 2013. The Phytophthora sojae Avrld gene encodes an RxLR-dEER effector with presence and absence polymorphisms among pathogen strains. Mol. Plant-Microbe Interact. 26:958-968.

Yoder, O. 1980. Toxins in plant pathogenesis. Annu. Rev. Phytopathol. 18:103-129.

Yu, Y., Zhang, Y., Yin, L., and Lu, J. 2012. The mode of host resistance to Plasmopara viticola infection of grapevines. Phytopathology 102:1094 1101. 